\title{
Honoring Harold A. Mooney: Citizen of the world and catalyst for invasion science
}

\author{
Daniel Simberloff $(\mathbb{D} \cdot$ Laura A. Meyerson $(\mathbb{D} \cdot$ Petr Pyšek $(\mathbb{D} \cdot$ David M. Richardson $(\mathbb{D}$
}

(C) Springer International Publishing AG 2017

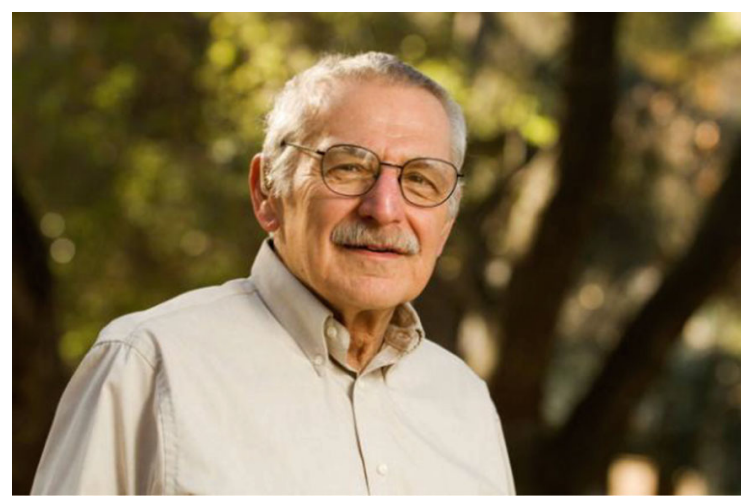

Photo by Linda Cicero, Stanford News Service

\section{Simberloff}

Department of Ecology and Evolutionary Biology, University of Tennessee, Knoxville, TN 37996, USA

\section{A. Meyerson ( $\square)$}

Department of Natural Resources Science, University of Rhode Island, Kingston, RI 02881, USA

e-mail: lameyerson@uri.edu

P. Pyšek

Institute of Botany, Department of Invasion Ecology, The Czech Academy of Sciences, 25243 Průhonice, Czech Republic

\section{P. Pyšek}

Department of Ecology, Faculty of Science, Charles University, Viničná 7, 12844 Prague, Czech Republic

\section{M. Richardson}

Centre for Invasion Biology, Department of Botany and Zoology, Stellenbosch University, Matieland 7602, South Africa
Although several authors have anointed Charles Elton the father of invasion biology (e.g., Richardson and Pyšek 2007, 2008; Ricciardi and MacIsaac 2008), and Charles Darwin anticipated a remarkable number of the concepts that have shaped the modern field (Ludsin and Wolfe 2001), Harold Mooney is the most important figure in stimulating the explosive growth of invasion science that began in the 1980s (Simberloff 2011). The major genesis of the modern field can be traced to the Third International Conference on Mediterranean-Type Ecosystems held in Stellenbosch, South Africa, in 1980 (Mooney 1998). Despite Elton's broad-ranging synthesis of the ecology of invasions (Elton 1958), the general topic of invasions was not a prominent part of ecological research at the time (Hui and Richardson 2017). Mooney (pers. comm.) recalls a definitive incident during a conference field trip, when delegates saw conifers invading undisturbed fynbos vegetation. Mooney and South African ecologist Fred Kruger were inspired to propose that SCOPE (Scientific Committee on Problems in the Environment) sponsor a program of workshops and conferences on plant invasions in Mediterranean-type ecosystems. It is noteworthy that, in 1973, Francesco di Castri and Mooney had edited the book 'Mediterranean Type Ecosystems', in which many chapters dealt with introduced species.

At the SCOPE General Assembly in 1982 in Ottawa, Ralph Slatyer, noting that SCOPE's mandate was to advance scientific understanding of globally significant environmental problems, moved that the proposed program deal with all invasions, not just those of Mediterranean-type ecosystems. The SCOPE assembly enthusiastically endorsed the program, 
appointing Mooney as chair of the SCOPE Programme on the Ecology of Biological Invasions. This program included many workshops, engaging at least 200 participants and leading to ten books from 1986 through 1991, of which two particularly influential volumes were those on invasions of North America and Hawaii (Mooney and Drake 1986) and a global synthesis (Drake et al. 1989). Citations of these two books sharply increased in the mid-1990s, and the program can plausibly be said to have kick-started the modern synthesis that now constitutes the field of invasion biology (Simberloff 2011) or, as is now increasingly recognized, invasion science (Richardson 2011; Vaz et al. 2017). The SCOPE program engaged a disparate group of scientists, some of whom had studied particular invasions of animals or plants and others of whom had worked on other aspects of ecology or evolution but not specifically invasions. It brought together scientists from many nations who worked in marine, freshwater, and terrestrial systems, as well as laboratory scientists and theoreticians.

Mooney's contributions to the founding and development of invasion science extend far beyond his spearheading and chairing of the SCOPE program. His personal research program has dealt with many aspects of invasion science, from empirical work on processes and impacts of plant invasions through conceptual contributions organizing and expanding the scope of the field and suggesting and encouraging policy initiatives to counter invasion impacts. As the éminence grise of invasion science, he has fostered the field in numerous ways. He was a signatory of the petition presented to then-Vice President Gore that eventuated in President Clinton's Executive Order 13112 of 1999, which established the United States National Invasive Species Council and led to promulgation of the first US national invasive species management plan in 2001. Also in 1999, he was a founding board member of the journal Biological Invasions, of which he is currently a board member emeritus. As an editorial board member of the Springer series Ecological Studies, Mooney shepherded not only the North American SCOPE volume to publication but also volumes on invasions in New Zealand (Allen and Lee 2006), invasions generally (Nentwig 2007), and marine invasions (Rilov and Crooks 2009). Another of his interests, closely allied to invasions, is the relationship between biodiversity and ecosystem function. To this end he helped launch in 1991 another
SCOPE program, on Ecosystem Functioning of Biodiversity (Mooney et al. 1996a), which, like the SCOPE invasions program, engaged scientists from many nations in an extended series of workshops and conferences. Mooney served on the scientific advisory committee that guided this program, and resulting studies, such as the synthesis volume (Mooney et al. 1996b) and a volume on islands (Vitousek et al. 1995), dealt with many aspects of introduced species.

Much of Mooney's voluminous empirical research corpus is devoted to plant physiology and life history. Increasingly, beginning in the 1980s, his work addressed the intersections of aspects of plant biology with ecological disturbance, as highlighted in a volume he edited on ecosystem impacts of disturbance (Mooney and Godron 1983), which is replete with many discussions of biological invasions (e.g., Mooney et al. 1983).

Over his long career, Mooney has published more than 280 papers with over 36,000 citations (as of June 2017), as well as numerous books and book chapters on multiple topics in ecology. His influence on invasion science is astonishing, especially given the relatively limited number of papers that focus on invasive species. A search on Web of Science (with invas*, alien, exotic and non-native among 'Topic') reveals that he has published only 17 papers that deal explicitly with invasions, with 23 co-authors (excluding those in Simberloff et al. 2011). However, his most cited paper, which thus far has received 3865 citations, is related to biological invasions (Vitousek et al. 1997), and two other invasion-focused papers are also among his Top 10 cited papers: Dukes and Mooney (1999) (720 citations) and Mooney and Cleland (2001) (700 citations). Overall, the 17 invasion-related papers account for $20 \%$ of Mooney's total citations, with an average of 455 citations per paper.

Also interesting, besides the huge impact of those papers, is the broad range of topics he managed to cover (Table 1). He seems to have touched many of the main topics that are still in research focus today. Mooney started to publish on invasions in the 1980s, with studies of community processes related to invasion, mostly from the perspective of the dynamics of soil resources, rainfall, and changes in community structure (Hobbs and Mooney 1986, 1991; Huenneke et al. 1990; Hobbs et al. 2007; Peters et al. 2007), but he was also interested in the physiology of invasive plant species (Nilsen et al. 1993). His list of publications includes papers focused on impact as early as in the late 1990s, long before it became a mainstream topic in 
Table 1 Overview of Harold Mooney's invasion papers by topic (only papers registered on Web of Science are presented) and books focusing on biological invasions

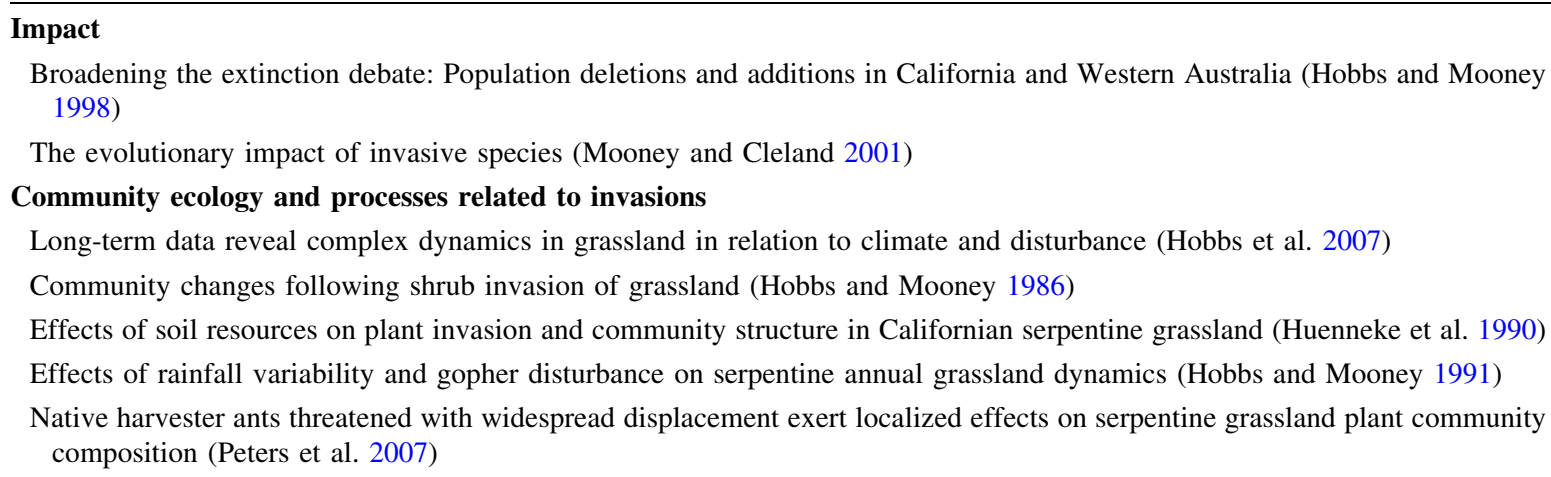

\section{Ecosystem ecology, processes and services}

Invasive species, ecosystem services and human well-being (Pejchar and Mooney 2009)

Disruption of ecosystem processes in western North America by invasive species (Dukes and Mooney 2004)

\section{Human-related drivers of biological invasions, global change and policy issues}

Human domination of Earth's ecosystems (Vitousek et al. 1997)

Invasive alien species in an era of globalization (Meyerson and Mooney 2007)

The United States, China, and invasive species: present status and future prospects (Jenkins and Mooney 2006)

Does global change increase the success of biological invaders? (Dukes and Mooney 1999)

\section{Restoration and invasive species removal}

Viewing invasive species removal in a whole-ecosystem context (Zavaleta et al. 2001)

Physiology

Patterns of stem photosynthesis in two invasive legumes (Spartium junceum, Cytisus scoparius) of the California coastal region (Nilsen et al. 1993)

\section{Edited books focusing on invasions}

Biological invasions: a global perspective (Drake et al. 1989)

Mediterranean type ecosystems: origin and structure (di Castri and Mooney 1973)

Ecology of biological invasions of North America and Hawaii (Mooney and Drake 1986)

Invasive alien species (Mooney et al. 2005)

Invasive species in a changing world (Mooney and Hobbs 2000)

Bioinvasions and globalization: ecology, economics, management and policy (Perrings et al. 2010)

invasions - these papers focus on key areas of impact, including extinctions of native species (Hobbs and Mooney 1998; Peters et al. 2005) and evolutionary aspects of impact (Mooney and Cleland 2001).

Towards the end of the century, Mooney's interest turned to big issues of the Anthropocene in which invasive species play a central role, such as humanrelated drivers of biological invasions, global change, and policy issues, and he coauthored several milestone papers (Vitousek et al. 1997; Dukes and Mooney 1999; Jenkins and Mooney 2006; Meyerson and Mooney 2007). This is also when he published several key papers on invasions in relation to ecosystem ecology, processes, and services (Dukes and Mooney
2004; Pejchar and Mooney 2009) and restoration and invasive species removal (Zavaleta et al. 2001).

Mooney's contributions to the expanded ambit of invasion science include integration of invasions into the catalog of major global environmental changes (e.g., Dukes and Mooney 1999; Mooney and Hobbs 2000; Sala et al. 2000; Hobbs and Mooney 2005; Lucier et al. 2006; Meyerson and Mooney 2007), the birth of the new field of invasion economics (Perrings et al.2010), and the development of the entire branch of ecology focused on ecosystem services (e.g., Ehrlich and Mooney 1983; Mooney and Ehrlich 1997; Carpenter et al. 2009), with particular attention to the impacts of invasions on ecosystem services (e.g., 
Pejchar and Mooney 2009), including through their effects via changes in ecosystem functioning with decreased biodiversity (Schultze and Mooney 1994).

Mooney's key role in the explosive global growth of invasion science should be seen in the context of his strong participation in the globalization of ecological thought (Mooney 1998; Richardson 2000). For example, he was a key participant in the International Geosphere-Biosphere Program in the 1980s that crystallized a number of research threads into a coherent science of ecological processes at a global scale, the Millennium Ecosystem Assessment of 2005 (e.g.,
Carpenter et al. 2006), and the Global Invasive Species Programme (GISP) that was a sequel to the initial SCOPE invasions program (Barnard and Waage 2004).

Mooney played a crucial role in starting regional initiatives for dealing with invasive species in many parts of the world. For example, in a review of the emergence of scientific capacity in invasion science in South Africa, van Wilgen et al. (2016) single Mooney out as the one international person who played a pivotal role through his "exceptional leadership qualities, diplomatic skills and warmth of person." Mooney has also acted as academic supervisor or

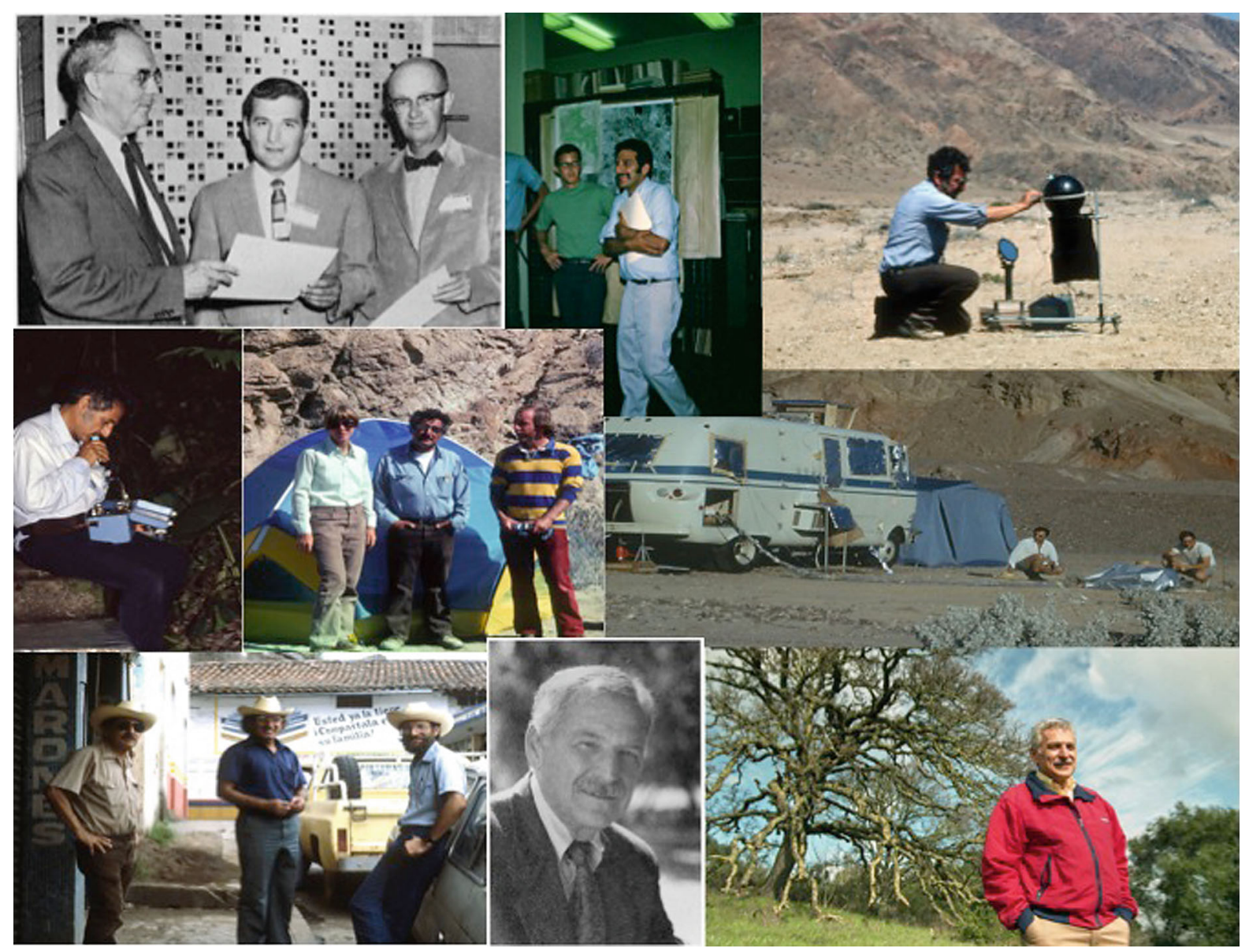

Photographs of Harold A. Mooney in action over his career. From left to right, 1. Harold Mooney, 1962, receiving the Ecological Society of America Mercer Award (Photo reproduced the Bulletin of the Ecological Society of America, Vol. 43, No. 4 (Dec., 1962), pp. 110-112.); 2. Harold Mooney, 1976 (Photo by Christopher Field); 3. Harold Mooney in the Atacama Desert 1979 (Photo by James Ehleringer); 4. Harold Mooney at Las Tuxtla, circa 1980. (Photo by Christopher Field); 5. Harold Mooney with Nora Chiariello and James Ehleringer in the Atacama Desert (1980); 6. Harold Mooney and Ty Harrison in Death Valley, circa 1980 (Photo by Christopher Field); 7. Harold Mooney (left) with Fakhri Bazzaz and Christopher Field in Catemaco, 1980 (Photo by Nora Chiariello); 8. Harold Mooney, Eminent Ecologist Award 1996 (Source:Bulletin of the Ecological Society of America, Vol. 78, No. 1 (Jan., 1997), pp. 16-17); 9. Harold Mooney Circa 2000 (Photo by Linda Cicero, Stanford News Service). 
career mentor for many researchers who now occupy prominent positions around the world. Although his attention has focused on wider environmental issues in recent years (Carpenter et al. 2009; Daily et al. 2009; Hobbs et al. 2011), he has maintained a strong interest in invasion science (Mooney 2011), and he has served as the pivotal ambassador for the field in influential global forums.

We honor and thank Hal Mooney for his leadership and insights in the field of invasion science. He has been a pioneer, a mentor and colleague to many of us, and a friend. His generosity, kindness, and encouragement have supported many invasion scientists over the last several decades. Hal's continuing contributions shape and influence our field and for this we owe him a great debt.

Acknowledgements We thank Chris Field, Nora Chiariello, and Jim Ehleringer for sharing their personal photos with us to include in this tribute. We also thank Liza Lester at the Ecological Society of America for her assistance and Yiannis Katsamakis from the Stanford Woods Institute for his help.

\section{References}

Allen RB, Lee WG (eds) (2006) Biological invasions in New Zealand. Springer, Berlin. doi:10.1007/3-540-30023-6

Barnard P, Waage JK (2004) Tackling species invasions around the world: regional responses to the invasive alien species threat. Global Invasive Species Programme, Cape Town

Carpenter SR, DeFries RS, Dietz T, Mooney HA, Polasky S, Reid WV, Scholes RJ (2006) Millennium ecosystem assessment: research needs. Science 314:257-258. doi:10. 1126/science. 1131946

Carpenter SR, Mooney HA, Agard J, Capistrano D, DeFries RS, Diaz S, Dietz T, Duraiappah AK, Oteng-Yeboah A, Pereira HM, Perrings C, Reid W, Sarukhan J, Scholes RJ, Whyte A (2009) Science for managing ecosystem services: beyond the millennium ecosystem assessment. Proc Nat Acad Sci USA 106:1305-1312. doi:10.1073/pnas.0808772106

Daily GC, Polasky S, Goldstein J, Kareiva PM, Mooney HA, Pejchar L, Ricketts TH, Salzman J, Shallenberger R (2009) Ecosystem services in decision making: time to deliver. Front Ecol Environ 7:21-28. doi:10.1890/080025

di Castri F, Mooney HA (eds) (1973) Mediterranean type ecosystems: origin and structure. Springer, Berlin. doi:10. 1007/978-3-642-65520-3

Drake JA, Mooney HA, di Castri F, Groves RH, Kruger FJ, Rejmánek M, Williamson M (eds) (1989) Biological invasions: a global perspective. Wiley, Chichester. doi:10. 1126/science.248.4951.88-a

Dukes JS, Mooney HA (1999) Does global change increase the success of biological invaders? Trends Ecol Evol 14:135-139. doi:10.1016/S0169-5347(98)01554-7
Dukes JS, Mooney HA (2004) Disruption of ecosystem processes in western North America by invasive species. Rev Chilena de Historia Natural 77:411-437. doi:10.4067/ S0716-078X2004000300003

Ehrlich PR, Mooney HA (1983) Extinction, substitution, and ecosystem services. Bioscience 33:248-254. doi:10.2307/ 1309037

Elton CS (1958) The ecology of invasions by animals and plants. Methuen, London. doi:10.1007/978-1-4899-7214-9

Hobbs RJ, Mooney HA (1986) Community changes following shrub invasion of grassland. Oecologia 70:508-513. doi:10.1007/BF00379896

Hobbs RJ, Mooney HA (1991) Effects of rainfall variability and gopher disturbance on serpentine annual grassland dynamics. Ecology 72:59-68. doi:10.2307/1938902

Hobbs RJ, Mooney HA (1998) Broadening the extinction debate: population deletions and additions in California and Western Australia. Conserv Biol 12:271-283. doi:10. 1111/j.1523-1739.1998.96233.x

Hobbs RJ, Mooney HA (2005) Invasive species in a changing world: the interaction between global change and invasives. In: Mooney HA, Mack RN, McNeely JA, Neville LE, Schei PJ, Waage JK (eds) Invasive alien species: a new synthesis. Island Press, Washington, DC, pp 310-331

Hobbs RJ, Yates S, Mooney HA (2007) Long-term data reveal complex dynamics in grassland in relation to climate and disturbance. Ecol Monogr 77:545-568. doi:10.1890/061530.1

Hobbs RJ, Hallett LM, Ehrlich PR, Mooney HA (2011) Intervention ecology: applying ecological science in the twentyfirst century. Bioscience 61:442-450. doi:10.1525/bio. 2011.61.6.6

Huenneke LF, Hamburg SP, Koide R, Mooney HA, Vitousek PM (1990) Effects of soil resources on plant invasion and community structure in Californian serpentine grassland. Ecology 71:478-491. doi:10.2307/1940302

Hui C, Richardson DM (2017) Invasion dynamics. Oxford University Press, Oxford. doi:10.1093/acprof:oso/ 9780198745334.001.0001

Jenkins PT, Mooney HA (2006) The United States, China, and invasive species: present status and future prospects. Biol Invasions 8:1589-1593. doi:10.1007/s10530-005-5852-z

Lucier A, Palmer M, Mooney H, Nadelhoffer K, Ojima D, Chavez F (2006) Ecosystems and climate change: research priorities for the U.S. Climate Change Science Program. Recommendations from the Scientific Community. Report on an Ecosystems Workshop, prepared for the Ecosystems Interagency Working Group. Special Series No. SS-92-06, University of Maryland Center for Environmental Science, Chesapeake Biological Laboratory, Solomons, MD, USA

Ludsin SA, Wolfe AD (2001) Biological invasion theory: Darwin's contributions from the origin of species. Bioscience 51:780-789. doi:10.1641/0006-3568(2001)051[0780: BITDSC]2.0.CO;2

Meyerson LA, Mooney HA (2007) Invasive alien species in an era of globalization. Front Ecol Environ 5:199-208. doi:10. 1890/1540-9295(2007)5[199:IASIAE]2.0.CO;2

Mooney HA (1998) The globalization of ecological thought. Excellence in Ecology 5. Ecology Institute, Oldendorf/ Luhe 
Mooney H (2011) Foreword. In: Richardson DM (ed) Fifty years of invasion ecology: the legacy of Charles Elton. Blackwell, Oxford, pp xi-xii

Mooney HA, Cleland EE (2001) The evolutionary impact of invasive species. Proc Natl Acad Sci USA 98:5446-5451. doi:10.1073/pnas.091093398

Mooney HA, Drake JA (eds) (1986) Ecology of biological invasions of North America and Hawaii. Springer, New York. doi:10.1007/978-1-4612-4988-7

Mooney HA, Ehrlich PR (1997) Ecosystem services: a fragmentary history. In: Daily G (ed) Nature's services: societal dependence on natural ecosystems. Island Press, Washington, DC, pp 11-19

Mooney HA, Godron M (1983) Disturbance and ecosystems. Springer, Berlin. doi:10.1007/978-3-642-69137-9

Mooney HA, Hobbs RJ (eds) (2000) Invasive species in a changing world. Island Press, Washington, DC

Mooney HA, Gulmon SL, Johnson ND (1983) Physiological constraints on plant-chemical defenses. ACS Symp Ser 208:21-36. doi:10.1021/bk-1983-0208.ch002

Mooney HA, Cushman JH, Medina E, Sala OE, Schulze ED (1996a) The SCOPE ecosystem functioning of biodiversity program. In: Mooney HA, Cushman JH, Medina E, Sala OE, Schulze E-D (eds) Functional roles of biodiversity: a global perspective. Wiley, New York, pp 1-6

Mooney HA, Cushman JH, Medina E, Sala OE, Schulze E-D (eds) (1996b) Functional roles of biodiversity: a global perspective. Wiley, New York

Mooney HA, Mack RN, McNeely JA, Neville LE, Schei PJ, Waage JK (eds) (2005) Invasive alien species: a new synthesis. Island Press, Washington DC

Nentwig W (ed) (2007) Biological invasions. Springer, Berlin. doi:10.1007/978-3-540-36920-2

Nilsen ET, Karpa D, Mooney HA, Field C (1993) Patterns of stem photosynthesis in two invasive legumes (Spartium junceum, Cytisus scoparius) of the California coastal region. Amer J Bot 80:1126-1136. doi:10.2307/2445540

Pejchar L, Mooney HA (2009) Invasive species, ecosystem services and human well-being. Trends Ecol Evol 24:497-504. doi:10.1016/j.tree.2009.03.016

Perrings C, Mooney HA, Williamson M (eds) (2010) Bioinvasions and globalization: ecology, economics, management, and policy. Oxford University Press, Oxford. doi:10.1525/ bio.2010.60.8.15

Peters HA, Chiariello NR, Mooney HA, Levin SA, Hartley AE (2005) Native harvester ants threatened with widespread displacement exert localized effects on serpentine grassland plant community composition. Oikos 109:351-359

Peters HA, Hsu G, Cleland EE, Chiariello NR, Mooney HA, Field CB (2007) Responses of temporal distribution of gastropods to individual and combined effects of elevated $\mathrm{CO}_{2}$ and $\mathrm{N}$ deposition in annual grassland. Acta Oecol 31:343-352. doi:10.1016/j.actao.2007.01.005

Ricciardi A, MacIsaac HJ (2008) The book that began invasion ecology. Nature 452:34. doi:10.1038/452034a
Richardson DM (2000) On global ecology. Global Ecol Biogeogr 9:182-184

Richardson DM (2011) Invasion science: the roads travelled and the roads ahead. In: Richardson DM (ed) Fifty years of invasion ecology: the legacy of Charles Elton. Blackwell, Oxford, pp 397-407. doi:10.1002/9781444329988.ch29

Richardson DM, Pyšek P (2007) Classics in physical geography revisited: Elton, C. S. 1958: the ecology of invasions by animals and plants. Progr Phys Geogr 31:659-666. doi:10. 1177/0309133307087089

Richardson DM, Pyšek P (2008) Fifty years of invasion ecology: the legacy of Charles Elton. Divers Distrib 14:161-168. doi:10.1111/j.1472-4642.2008.00464.x

Rilov G, Crooks JA (2009) Biological invasions in marine ecosystems. Springer, Berlin

Sala OE, Chapin FS III, Armesto JJ, Berlow E, Bloomfield J, Dirzo R, Huber-Sanwald E, Huenneke LF, Jackson RB, Kinzig A, Leemans R, Lodge DM, Mooney HA, Oesterheld M, Poff LN, Sykes MT, Walker BH, Walker M, Wall DH (2000) Global biodiversity scenarios for the Year 2100. Science 287:1770-1774. doi:10.1126/science.287.5459. 1770

Schultze E-D, Mooney HA (1994) Ecosystem function of biodiversity. Springer, Berlin

Simberloff D (2011) Charles Elton: neither founder nor siren, but prophet. In: Richardson DM (ed) Fifty years of invasion ecology: the legacy of Charles Elton. Wiley-Blackwell, Oxford, pp 11-24. doi:10.1002/9781444329988.ch2

Simberloff D, Alexander JM, Allendorf F et al (2011) Nonnatives: 141 scientists object. Nature 475:36. doi:10.1038/ 475036a

Van Wilgen BW, Carruthers J, Cowling RM, Esler KJ, Forsyth AT, Gaertner M, Hoffman MT, Kruger FJ, Midgley GF, Palmer G, Pence GQK, Raimondo DC, Richardson DM, van Wilgen NJ, Wilson JRU (2016) Ecological research and conservation management in the Cape Floristic Region between 1945 and 2015: history, current understanding and future challenges. Trans Roy Soc S Afr 71:207-303. doi:10.1080/0035919X.2016.1225607

Vaz AS, Kueffer C, Kull CA, Richardson DM, Schindler S, Muñoz-Pajares AJ, Vicente JR, Martins J, Hui C, Kühn I, Honrado JP (2017) The progress of interdisciplinarity in invasion science. Ambio 46:428-442. doi:10.1007/ s13280-017-0897-7

Vitousek P, Loope LL, Adsersen H (eds) (1995) Islands. Biological diversity and ecosystem function. Springer, Berlin. doi:10.1007/978-3-642-78963-2

Vitousek PM, Mooney HA, Lubchenco J, Melillo JM (1997) Human domination of earth's ecosystems. Science 277:494-499. doi:10.1126/science.277.5325.494

Zavaleta ES, Hobbs RJ, Mooney HA (2001) Viewing invasive species removal in a whole-ecosystem context. Trends Ecol Evol 16:454-459. doi:10.1016/S01695347(01)02194-2 